\title{
Aprender y enseñar a vivir en la incertidumbre
}

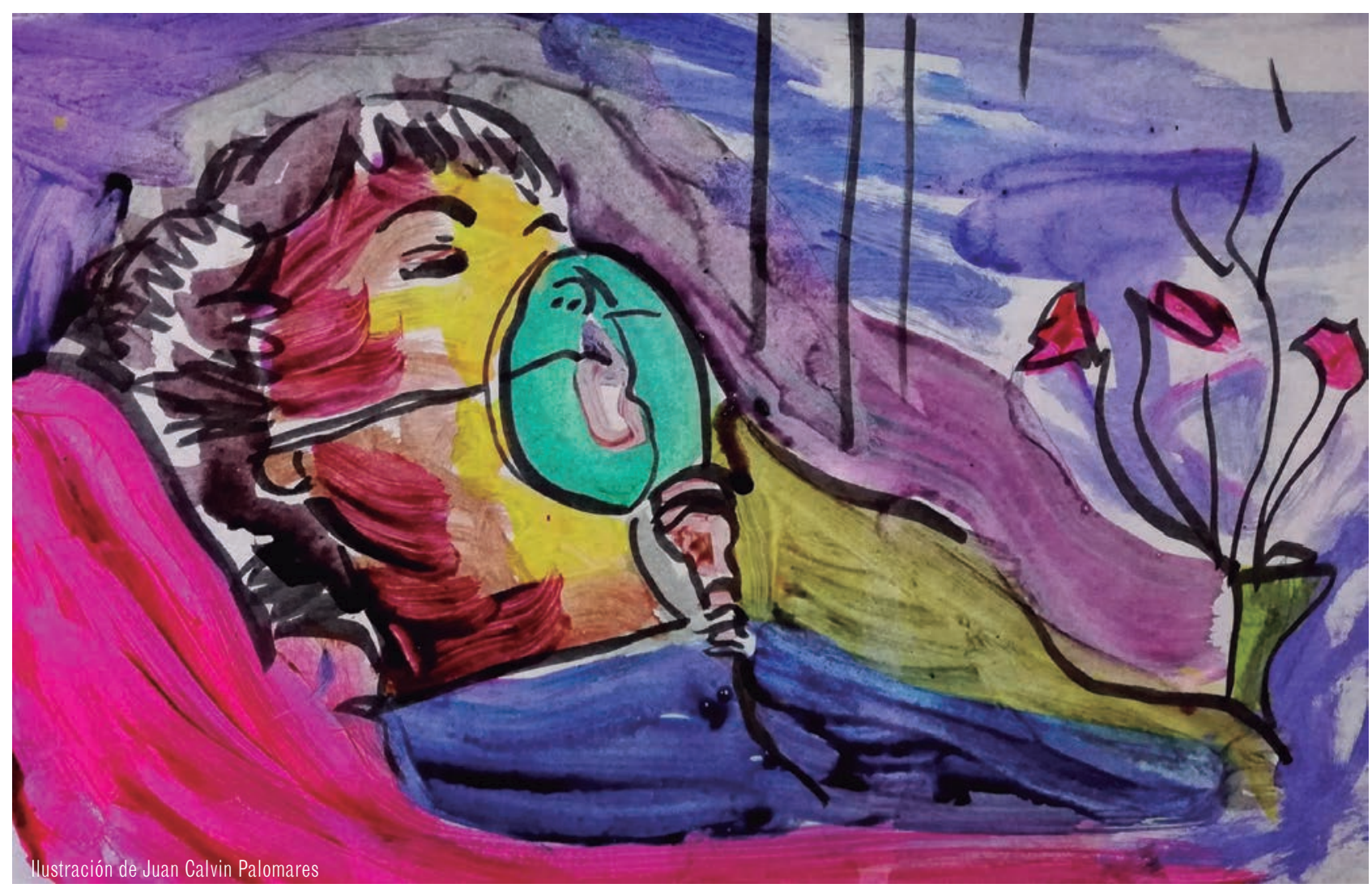

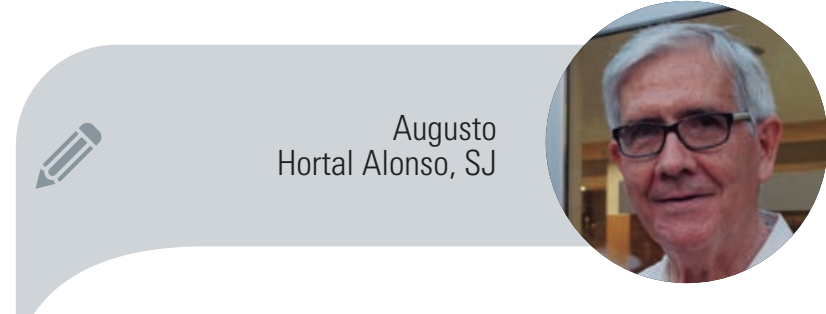

Universidad Pontificia Comillas ahortal@comillas.edu

Por si lo habíamos olvidado, las medidas de aislamiento social y confinamiento han venido a recordarnos que educar, más que impartir conocimientos - colgar competencias y destrezas al educando, es enseñar a vivir en el mundo tal como es, por ejemplo, en un mundo en el que hay pandemias que nos obligan a vivir de forma diferente a como vivíamos.

Solemos decir que para educar a un niño se necesita a toda la tribu. Antes de la pandemia la tribu vivía fragmentada en subtribus: unos en sus aulas, otros en sus lugares de trabajo, los viejos en sus residencias y los enfermos en sus hospitales. El confinamiento ha venido a hacernos vivir como una única tribu que se puede contagiar y que tiene que luchar contra el contagio. Confinados y distanciados, nunca habíamos estado más centrados todos en un solo asunto. Hacía tiempo que la tribu no estaba tan unida a pesar de estar dispersa.

Es la ocasión de aprender y enseñar a vivir en un mundo en el que unos enferman y otros nos/los cuidan, unos mueren y otros los lloran, unos se aíslan y otros se preocupan de que no falte lo necesario... Aprender a vivir en un mundo en el que la vida cotidiana no es como era. Cosas ordinarias como pisar la calle, ir a clase o hacer deporte se han vuelto algo insólito, añorado, prohibido. Cosas que eran extraordinarias se están convirtiendo en ordinarias como la intensidad de la convivencia familiar.

Cada familia tiene su propia historia en esta pandemia. Aquí me quiero fijar en una faceta omnipresente y presumiblemente duradera con la que hay que aprender y enseñar a vivir: vivir en un mundo de 
Las rulinas de la vida colidiana de

antes nos hacían creer que las cosas
son como son y van a seguir sienda
como son y como eran. Hay que estar
preparados para lo inesperado y la
sorpresa

incertidumbres. Por no saber, no sabemos con certeza si tenemos o no tenemos el dichoso virus, si contagiamos o nos pueden contagiar, o si somos inmunes, y todo ello por cuánto tiempo. Las rutinas de la vida cotidiana de antes nos hacían creer que las cosas son como son y van a seguir siendo como son y como eran. Hay que estar preparados para lo inesperado y la sorpresa. Hay que saber apreciar como un regalo lo que sucede cada día; no está garantizado; hay que estar preparado para vivir circunstancias inesperadas, sorprendentes.

En mi infancia, al irnos a dormir y dar un beso a nuestros padres, era común decir y escuchar: "Hasta mañana si Dios quiere...". Esta expresión, en mi vida de hijo de familia, fue tan cotidiana que prácticamente era con la que nos despedíamos y deseábamos las buenas noches. Alguna vez, ya en la cama, empezando a entrar en somnolencia, te quedabas pensando: "¿querrá o no querrá?". Al despertar al día siguiente sentías un alivio agradecido por el nuevo día que recibías como un regalo: "se ve que ha querido".

Andando el tiempo me sorprendió gratamente encontrar estos versículos de la Carta de Santiago que parecían haber inspirado esa costumbre de despedir el día con un "Hasta mañana si Dios quiere...":

«En cuanto a vosotros, los que decís: "Hoy o mañana iremos a tal ciudad y pasaremos allí el año negociando y enriqueciéndonos", ¿sabéis acaso qué os sucederá mañana? Pues vuestra vida es como una nube de vapor, que aparece un instante y al punto se disipa. Haríais mejor en decir: "Si el Señor quiere, viviremos y haremos esto o aquello"».

SANT $4,13-15$

Con el tiempo esa expresión cayó en desuso. Al dejar de usarla nos acostumbramos a pensar que está poco menos que garantizado que cada día va a ser más o menos como el anterior... hasta que vino el coronavirus a recordarnos que no es así, al menos que no está garantizado. El Señor de los tiempos, el Padre del siglo futuro es el Señor de nuestras horas

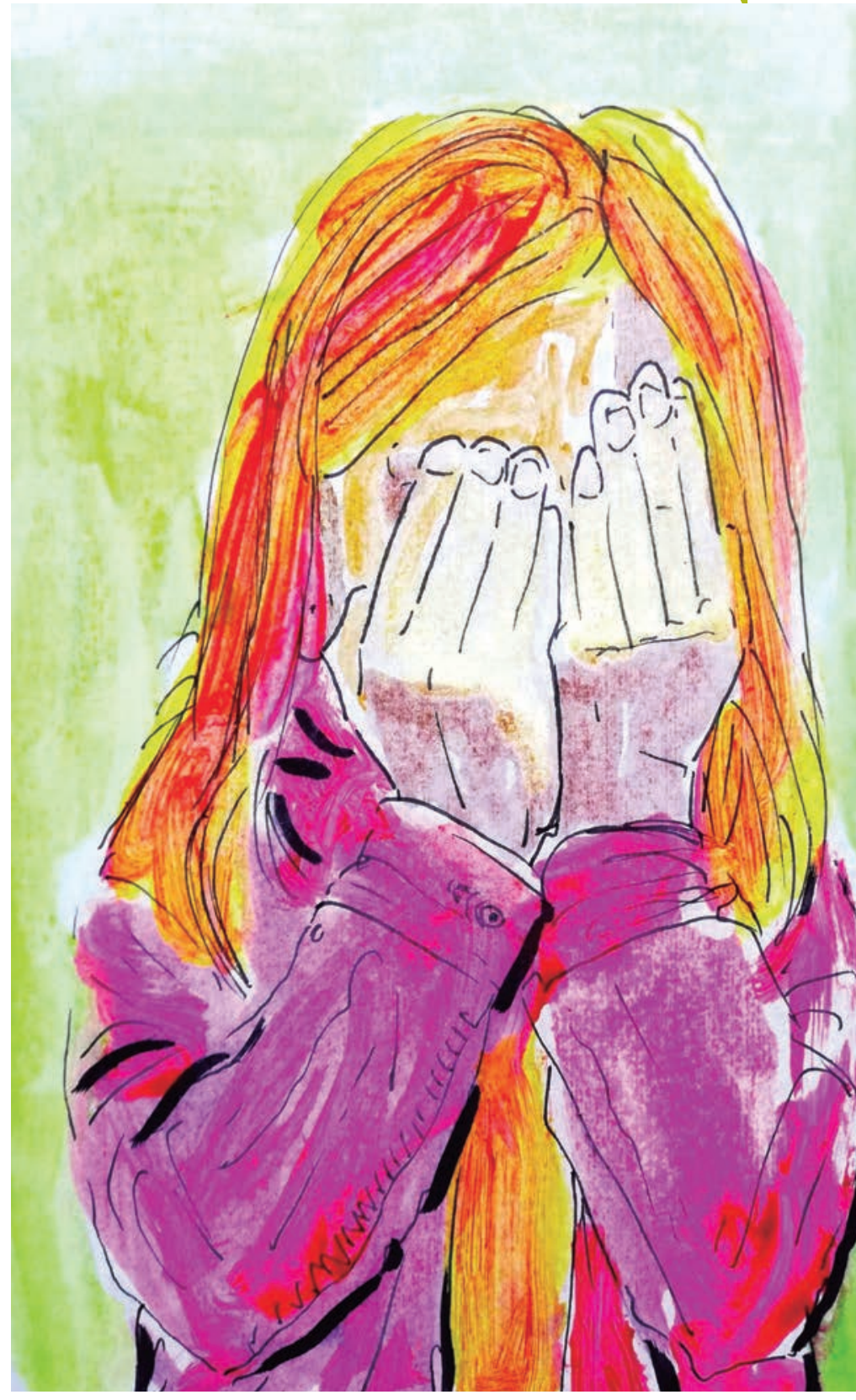

Ilustración de Juan Calvin Palomares

y de nuestros días. Hay que contar con él para lo imprevisto y para lo de siempre, para lo bueno y para lo malo, para las puertas que se cierran y las oportunidades que se abren. Hay que agradecerle incluso las regularidades físicas del mundo que él creó y en el que nos situó su fidelidad bondadosa:

«Dice una leyenda judía que cuando los dos primeros seres humanos rechazaron a Dios el día de su creación y fueron expulsados del Edén, vieron ponerse el sol por primera vez. Entonces quedaron horrorizados, porque no podían entender otra cosa sino que por su culpa el mundo volvería a precipitarse en el caos. Sentados uno frente al otro, lloraron toda la noche y se verificó su conversión. Entonces comenzó a amanecer. Adán se levantó, tomó un unicornio y lo ofreció como sacrificio en lugar de sí mismo».

Martin Buber, Eclipse de Dios • 